\title{
GOOD GOVERNANCE APPROACHES OF THE CAPITALIZATION OF NATURAL RESOURCES IN INNOVATION FORMS OF ECONOMY
}

Klynovyi D. V.

\section{Introduction}

Today in our country it is difficult to find a person who would never asked himself: why domestic economy is so inefficient? Is our country rich or poor? Still, herewith, each one usually has his own convenient answer that mostly refers to nature. In particular, because of limited scope of resources. People involved in different branches of business and public administration often complain about the lack of numerous mineral and energy resources - natural gas, oil, fresh water, environmental issues including limitations connected with land and forest etc. This concerns also to science, which allegedly failed to provide convincing answers ensuring positive development trends.

But it's necessary to take a step forward and perceive such a position as one's own, evaluate it critically in order to reveal the essence of what happens indeed and, in the end, concentrate on the prospects, understanding that we also are a part of nature. Such approach becomes scientifically acceptable, as far as it is manifesting systemic thinking and logic, and leads to deep understanding that, actually, just a person should take responsibility for the condition of the economy and the state. The key to successful transformation of Ukraine's natural resource management systems is the development of the experience of these countries and the application of effective and modern economic models of management Good Governance, Public-Private Partnership, Corporate Social Responsibility, adapted to our national specifics.

Thus, the answer to the question whether Ukraine is rich or poor, lies in adequate overall economic assessment of natural resources and their successful implementation into full-fledged capital by all means and tools of the modern economy of the XXI century. The Rio 2012 resolutions are an important international documents that emphasizes that the institutionalization of the economic process and other modern economic 
tools in management of natural resources are main prerequisites for the continued sustainable development of society.

\section{Modern economic models for the use of natural wealth}

It is necessary to use modern approaches of natural capital management, which are based on accounting of natural capital wealth and capitalization of natural resources now. Thus, some researchers, such as L. Larush persists on making some essential adjustments to the economic theory of natural capital and take into account the abilities of the natural capital to create the cost without exhibit of the human labor. The Ukrainian representatives of scientific school of physical economy, for example S. Podolynskiy had also specified on this fact. It is also necessary to acknowledge that unlike other types of capital, in particular - financial capital, a natural capital possesses actual, but hidden usefulness which exists in hidden form. However, this fact was not taken into account by both researches. They considered, that any kind of wealth has only actually shown and represented features. As the result of it now the natural constituent is not represented valuably in the system of indexes of value of national wealth. The problem of the account of the cost of the natural capital in all goods and services is very actually in correspondence with the decisions of the world Summit in Rio de Janeiro - 2012 (Natural Capital Declaration).

One of the well-known scientists-ecologists - R. Simonetti, Coordinator of the Sustainable Finance Program had noted that socialenvironmental policy will be one of the key directions of the work of financial structures and a global statement may demonstrate the commitment to work towards integrating natural capital criteria into financial products and services, as it was launched at Rio+20. Thus, new for us conceptual approach includes, firstly, understanding of natural resource as a capital and, secondly, capitalization as a process of such resource transformation into surplus value and profit. This view is very important because, as it's widely known, that capital differs from wealth by its ability to generate profit. So, capital is wealth in an active state, involved at the certain moment into economic turnover. And we need to find out how a particular natural resource of a certain area can be transformed into a profitable business. Just here it becomes necessary to use the scientific achievements of this issue. And if in our country this 
direction is not yet sufficiently developed, we should use positive experience already gained abroad.

Thereby, specific recommendations of the Rio+20 contain information about the natural capital effect on the economic process. There are also some initial guidelines that show how natural resources, including water, land, forestry, minerals and other components of the environment should be adequately estimated. In addition, we find here a very important ratio of natural capital to capitals of other origin, namely human, industrial, financial etc., because it affects the state's economic policy. Moreover, welfare of every citizen largely depends on how seriously governments manage to consider these features. For example, in Scandinavia, the USA, India and even in some African countries governments have established specific financial funds of sovereign wealth, in which they concentrate revenues from natural assets in order to help the economies of these States in times of crisis.

It's also worth noting the report of R. Simonetti, coordinator of the Sustainable Finance (Brazil) at the Rio+20 summit, in which she made significant emphasis on the fact that the assessment and accounting of natural capital are of paramount importance to ensure successful changes towards sustainable development at a national level, and for the world economy as a whole. This question is very actual to our country also. In order to determine the directions of efficient, profitable solution of current environmental management issues, each and all should answer a question: our country is rich or poor? This problem per se should be considered as a cornerstone. If anybody's self-analysis prompts him that he is poor, his behavior will be distorted by lack of confidence as for his resources, capabilities and skills. But if, respectively, a person perceives himself as a rich man, he often feels ability to overcome any obstacles. Wealth implies something much more than it follows from commonplace perception of it as of availability of a certain amount of money, often quite large. Based on the analysis provided in this article, in our opinion, correct is the second attitude - we are rich because we live in a rich country, and it is not questioned. Everything else related to streamlining our way of life is secondary; therefore, corresponding problems can be overcome. It all depends on how quickly and effectively we would manage to reveal our ability to self-organization, self-improvement, adopting advanced world experience in this area in order to properly identify our goals and to achieve them. 
Overall, given the Rio +20 recommendations, it is reasonable to talk not only about the Ukraine's natural wealth in general, but also by regions. This purports the need for a differentiated approach to its evaluation, since there is a significant difference both in regional variety and in resources availability in certain areas. For example, three administrative regions of Ukraine - Donets'k, Lugans'k and Dnipropetrovs'k - account for 80\% of Ukraine's reserves of mineral resources. At the same time the Donbas area belongs to the poorest in water availability: Donets'k and Lugans'k regions account for less than $5 \%$ of the country's water resources each. In this regard, other issues emerge. For example, why Podillya, the richest agricultural area from year to year appears among regions with the lowest indicators of economic development? And Carpathian region which is widely praised as a real pearl on the tourist and resort map of Europe - to permanently subsidized territories? Why the richest resources availability of some regions of Ukraine, for example, Chernigiv, with a distance to Kiev less than one hour by car, where concentrated powerful oil wells, has virtually no effect on their economic situation? Why welfare of people in rural areas of the South of Ukraine remains in poor condition, although natural wealth there, from the agricultural point of view, is presented by the world best black soils, having even the reference quality. Whether it's the time for Ukraine to talk about so-called "resource curse", which is characteristic for developing countries.

Thereof, it is necessary to take into account actual, but hidden and not shown usefulness, value features and system ecological characteristic in each type of resource - land, water, wood and mineral resources, and in ecological system capital, created by all set of productive force of naturalanthropogenous ecological systems, which comprise all available types of resources. For example, hidden and undervalued characteristics of the natural capital can be presented in virtual water, in the price of the economic wasted lands, in ground protection characteristic of timber plantings, in the risk factor in estimation of the mineral-raw materials capital. It is necessary to take into account the value and the cost of ecological system capital, which creates the conditions for selfreproduction of elements of the natural capital and provides the sustainable development of natural-economic systems.

One of key issues is the volume of our country's natural capital in terms of value. The main factor in the assessment of natural wealth - that's 
just a link between scientifically proven wealth concept and the current state of the economy. Wealth, according to modern economists, is measured not by potential, but namely by actual value at the time of evaluation of resources that may be involved in the economic turnover. Thus, the value of wealth greatly depends on the current economic situation and on its readiness to enter into economic circulation, so, in fact, on capitalization. The cost of natural wealth in Ukraine can be estimated only tentatively, given the low level of capitalization of available natural resources. Overall, the share of natural capital in national wealth structure is approximately the same as in the rest of the world - about one-third. Appositely, the rate of the Ukraine's natural wealth, calculated according to current techniques manuals, in 2019 , comprised in value terms a bit more than three with a half trillions UAH. However, considering, for instance, structural and quantitative indicators of the areas, comparable with Ukraine on natural resources and potential revenues that could be derived from nature, the order of the numerals might be different. The real value of natural wealth in comparative assessments and subject to achievement of higher levels of capitalization of all kinds of national natural resources under more favourable economic circumstances might comprise several trillions of US dollars.

Similar assumptions are supported by a number of factors: for example, in recent years in crops exportation Ukraine firmly ranked second in the world among individual states (behind the USA). Herewith the land related share in our national wealth in accordance with regulatory assessment is only slightly more than USD 60 billion. In our opinion, the current method of agricultural land assessment provides obviously underestimated figures, as far as it is oriented at unjustifiedly low prices for agricultural products, which potentially could be received from use of land. But in terms when in our country a real land market is practically absent, it's still too early to talk about complete assessment of the land related wealth. Similar statements could also be attributed to some other types of natural resources - water, forests, minerals etc. Therefore, in current economic situation our natural wealth as a whole - due to acting estimation methods - is, of course, largely underestimated - it's an objective reality. However, the figure exceeding three with a half trillion UAH is rather high, it corresponds to more than USD130 billion and exceeds the declared personal wealth of anyone among the richest people 
all over the world. For comparison, this amount is approximately equal to the value of almost 10 thousand tons of gold in the market prices taken for the relevant period. For its railway traffic it would be necessary to take about 200 standard freight cars clutched into five trains of 40 cars each. It's worth to be noted that here we deal only with one of the most modest indicators of currently available estimates of the natural capital of Ukraine, though most economically tangent to existing realities.

It is quite clear that the regional economic policy of our state requires appropriate legislative, regulatory and organizational improvements in order to implement the principle of economic self-sufficiency of regions, inseparable from efficient use of available natural resources, - the principle that should become a firm basis for the decentralization of environmental management. Of course, implementation of the newest regional economic policy in accordance with the requirements mentioned above presumes flexible use of the territorial resource potentials while steadily maintaining environmental security and providing relevant well-developed civil society institutions that fully meet the current market conditions.

Conceptual innovation approaches of "green", "blue" and "nano" economy forms the basis of new management toolbox. It is determined that the modernization of managerial system of natural resources must provide creation of the high effective infrastructure of full-fledged attraction of natural resources in economic process through capitalization of them, including financial component, connected with corporative forms of natural resources management.

In Ukraine new innovative approaches related to "nanoeconomics" are considered to be very important. According to this concept's current positions, proposed relatively recently by a Russian scientist G. Kleiner (2004) ${ }^{1}$, a primary link in the chain of business undertaking is deemed to be not a company, but a man together with a space of his creative activity, including microenvironment of his existence. Such approach presumably opens up broad prospects for development of small entrepreneurship and family business. Nanoeconomics endeavours to find out the most promising forms of behaviour of an individual citizen, including investment activity, entrepreneurship, subsistence farming, social security, etc. This view is especially relevant for rural area, where employment and self-employment issues are posed most acutely, that significantly affects the formation of the national archetype of the Ukrainian people.

\footnotetext{
${ }^{1}$ Kleiner, G. (2004). Nanoeconomics. Questions of Economy, 12, 70-93.
} 
With regard to the documents of the Rio +20 summit, to the most urgent issues belongs creation of models for sustainable territorial development that should be based on the concept of efficient local resources usage, first of all, as it obviously, natural. This allows to implement popular environmentally oriented concept of "blue" economy suggested by well-known Belgian economist G. Pauli who personally presented its core ideas, previously elaborated in his world famous book "The Blue Economy: 10 years - 100 innovations - 100 million jobs" (Pauli 2010 $)^{2}$, translated into Ukrainian and published in Kyiv in February 2012. In his scientific and journalistic writings G. Pauli argues that rational use of resources on each separate stage and every level of human activities is a prerequisite for economic competitiveness. This concept of nature-oriented existence, based on available local resources, simple and safe technology, small and medium-size business, offers ecosystem approach and cascade models for building the structure of production with a full-scale use of competitive advantages of municipal economic entities.

The term "green economy" was first coined in a pioneering 1989 report for the Government of the United Kingdom by a group of leading environmental economists, entitled Blueprint for a Green Economy (Pearce, Markandya and Barbier, 1989) ${ }^{3}$. The report was commissioned to advise the UK Government if there was a consensus definition to the term "sustainable development" and the implications of sustainable development for the measurement of economic progress and the appraisal of projects and policies. Apart from in the title of the report, there is no further reference to green economy and it appears that the term was used as an afterthought by the authors. Whilst the theme of the first Blueprint report was that economics can and should come to the aid of environmental policy, the sequels extended this message to global problems - climate change, ozone depletion, tropical deforestation, and resource loss in the developing world. All reports built upon research and practice in environmental economics spanning back several decades. In 2008, the term was revived in the context of discussions on the policy response to multiple global crises. In the context of the financial crisis and concerns of a global recession, UNEP championed the idea of "green stimulus packages" and

\footnotetext{
${ }^{2}$ Pauli, G. (2010). The Blue Economy: 10 years - 100 innovations - 100 million jobs. Boulder, CO: Paradigm Publishers, 386 p.

${ }^{3}$ Blueprint for a green economy : David Pearce, Anil Markandya and Edward B. Barbier. Earthscan, London, Great Britain (1989). 192 p.
} 
identified specific areas where large-scale public investment could kickstart a "green economy". There is no internationally agreed definition of green economy and at least eight separate definitions were identified in recent publications. For example, UNEP has defined the green economy as one that results in improved human well-being and social equity, while significantly reducing environmental risks and ecological scarcities: low carbon, resource efficient, and socially inclusive". This definition has been cited in a number of more recent reports, including by the UNEMG and the OECD. Another definition for green economy offered by the Green Economy Coalition (a group of NGOs, trade union groups and others doing grassroots work on a green economy) succinctly defines green economy as "a resilient economy that provides a better quality of life for all within the ecological limits of the planet" (Allen and Clouth, 2012).

The main on this way is to obtain deep awareness that the very concept of natural wealth should be transformed into a tool with which we will become able to make real steps in resolving development issues of the problem territories. But, as already mentioned, this requires determining successive efforts. As for science, its challenge presumes reorienting the $\mathrm{R} \& \mathrm{D}$ projects to more pragmatic tasks, with emphasis on what significant has been already achieved in the world, especially in European countries, in the field of natural resources transformation into an efficient and powerful capital of high liquidity.

In the nearest future we have not only to undertake a comprehensive valuation of natural capital, but also to provide all necessary backgrounds for launching its converting into financial shape. In particular, the appropriate GIS database is to be created to display characteristics of the natural capital allocation by regions of Ukraine. It's important to disclose the investment attractiveness of the country for the presence and size (extent) of natural capital, including primarily strategic resources such as oil, shale gas, coal, ores etc. The same concerns elaboration of corporate, project and other innovative software tools for natural resources management, including financial sovereign funds in the field of environmental management and more.

It's to be specially noted that forming of innovative, organizational and economic structures of environmental management should be carried

\footnotetext{
4 A guidebook to the Green Economy Issue 1: Green Economy, Green Growth, and Low-Carbon Development - history, definitions and a guide to recent publications Division for Sustainable Development, UNDESA: Cameron Allen and Stuart Clouth, UN Division for Sustainable Development, 2012. 64 p.
} 
on in line with the ideologem and objectives for sustainable development, which presumes shared participation and responsibility of national, regional, local authorities and businesses circles in managing natural resources, as well as in sufficient financing of environmental, investment, innovation and other programs of regional development. The concept of building of such structures is presently well known and encourages creation of cluster-corporate forms in natural resource management at all three levels of governance - national, regional and local. This will also ensure the authority decentralization with regard to the principle of structural control.

It should also be added that resources require securitization, that means: ensuring formation and emission of financial assets which are based on natural capital; creating conditions for such assets effective management through joint investment institutions, financial markets, stock exchange and "over-the-counter" (OTC) stock trading; promoting formation of financial resources flows aimed at the natural capital efficient use and restoration, as well as receiving and distribution rent-related incomes.in the interests of all participants in the process. In our opinion, all kinds of rents of natural origin, including not only traditional land, water, forestry and mining, but also climatic, resort as well as rents of geographical location, environmental, transport, etc., should be actively used as a source of public revenue.

Proceeding from fundamental systemic vision of the above mentioned provisions as an entire integrated mechanism of natural-resource relationships it is necessary to concentrate attention, primarily, on the aim that it should cover all stages of the economic cycle of production, exchange, distribution, consumption and accumulation of relevant investment component of economic activity.

In this context, it is necessary to focus on investment-project forms of environmental management, which provide desired tangible results simultaneously with guaranteed high financial returns and advantageous social and environmental effects of economic activity.

We must also take into account the fact, that in the world entirely new concepts of economic activity have been formed, the cornerstone of which human interests in harmonious interaction with nature. In particular, if Ukrainian public is partly aware of the core principles of "green" economy state custody in environmental protection, introduction of environmental 
restrictions, high taxes and severe penalties for pollution, upgrading of equipment and technology measures in wide-scale hazardous industries, transition to alternative energy sources etc. - the concept of capital-saving, low-waste and oriented towards the use of technologically clean production in innovative small and medium-size businesses of the "blue" economy is not yet known to everyone. In our country almost out of sight of many professional economists remains a concept of nano-economics, which is close to Ukrainian national mentality. It generally considers each individual person, ordinary citizen as a separate self-sufficient entity and, accordingly, imposes on him the duty of reproduction and protection of natural capital. As for existing natural wealth, just one as ultimate approach to solving problems of the natural resources efficient use scarcely should be recommended. On the contrary, it is necessary to implement in environmental management on the national, regional and local levels wide variety of modern means and measures for economic space organization in the direction of development of environmentally oriented economy.

\section{Good governance tools for modernization}

of the natural resources management system of Ukraine

Historically, the form of business management in Ukraine was determined from the outside, without taking into account peculiarities of psychology and traditions of the people. A similar process is now only increases. Given this, it's quite reasonable to focus on the second part of the question: what to do? Here it seems appropriate to put down some thoughts about relatively rather promising future. They refer to proper and effective use of our God-given natural wealth. It turns out that any wealth should be managed skilfully because otherwise, you risk to lose what you have. First of all, it's necessary to learn how to manage effectively. The process approach to management, according to which a variety of modern economical systems - from the quality management to environmental and personnel management - are being built, comes to the fore also among concepts of building national economies in many countries of the world. It is firmly associated with successes in socio-economic development and crisis phenomena overcoming in the Scandinavian countries, Canada, Japan, South Africa and so on. For us this task is quite complicated because it's difficult to think in different way about situation in which we have found ourselves more than twenty-five years ago with the transition 
to a completely new economic reality that required creation on its own resources a basis of strong independent economy integrated into the world economic community. Still so far, the opposite happened - using financial, energy and other resources involved from foreign countries we have managed to build only relatively weak economy, dependent on nonresidents, that is not in line with European practice.

For this purpose it's advisable to benefit from Polish experience. This country long since is maintaining strong tradition of decentralization and local self-governing given by the Magdeburg law. The government and local authorities are pursuing a policy that provides environmental safety for current and future generations of citizens. Environmental protection is deemed to be responsibility of all branches of the government which, in turn, at all levels encourages and supports citizens' initiatives aimed at protecting and improving the environment. For this, in particular, the concept "public authority" that covers the authorities at all levels is being widely applied. However, it should be noted that in Poland there is a developed system of local government that has three levels - Gmina, Powiatu and Województwo (consequently -municipality, province and Region).

The widest about authority in the use of natural resources is the level of a gmina - an amalgamated local community. Rights of gmina are profound in imposing local taxes, creating own financial base of environmental management and decision making in planning local resources usage as a basis for prospective area's development. In particular, gmina establishes agricultural and forestry taxes. Authority of powiatus regarding the natural resources is relatively limited. Their rights refer to water and gas supply for the population, provision of local fuels - coal, peat, firewood, etc. Competences at the level of Województwos spread out to certain issues of strategic management, including comprehensive reclamation works, but namely in the field of environmental management and disposal of natural resources their rights are also limited. High is a role of all local governance levels in fulfilment of economically viable projects that envisage development of such nature related objects, as fisheries, protected nature reservations, recreational facilities etc. In Poland the government and local authorities at all levels provide protection of natural sites of strategic importance. We also should note careful consideration and control over the country's natural resources, their economical use and protection under existing European standards in accordance with the EU Directives. 
Unlike Poland, the most significant among current problems of the majority of regions in Ukraine are incompleteness of inventory records of available natural resources, and low level of capitalization. Such situation is not conducive to their active involvement in economic turnover. Lack of appropriate institutional environment, as well as weak level of market institutions development, including the legislative framework, business structures and financial system in general, slows down the use of modern forms of corporate business entities that could provide solutions for sustainable socio-economic development of the regional natural resource complexes. In this regard, full economic assessment of natural wealth should become the core process in improvement economic activities as a whole.

Thus, we decisively need to shift the focus, to identify the principal points and concentrate attention and efforts on our own resources, benefits and opportunities, still awaiting implementation in the process of economic development. But together with the process, there is also a system which requires systemic thinking that we find too complicated and manage difficult. And most importantly, we yet don't know how to think effectively outside the particular business, region, social group, to think widely, on-state level, ignoring personal, corporate or group interests and ambitions. The key to successful transformation of Ukraine's natural resource management systems is the development of the experience of these countries and the application of effective and modern economic models of management - Good Governance, Public-Private Partnership, Corporate Social Responsibility, adapted to our national specifics.

There is offered modernization of managerial system of natural resources through introduction of mechanism of the "Good Governance", conception of corporative social and ecological responsibility and introducing of the system of standards series ISO 14000, including standard of estimation of the ecological-cost-performance of management ISO 14045 , with such parameters as an organizing structure and dispersion of responsibility in the system of corporative management, which is based on a mechanism of the public-private partnerships (PPP). Conception of Good Governance include participatory, decentralisation, following the rule of law, effective and efficient, accountable, transparent, responsive, equitable and inclusive models of management. Good governance is a term used in international development literature to describe various normative accounts of how public institutions ought to conduct public affairs and manage public 
resources. These normative accounts are often justified on the grounds that they are thought to be conducive to economic ends, such as the successful economic development. Different organizations have defined governance and good governance differently to promote different normative ends.

Good governance has 8 major characteristics. It is participatory, consensus oriented, accountable, transparent, responsive, effective and efficient, equitable and inclusive and follows the rule of law. It assures that corruption is minimized, the views of minorities are taken into account and that the voices of the most vulnerable in society are heard in decisionmaking. It is also responsive to the present and future needs of society.

Participation by both men and women is a key cornerstone of good governance. Participation could be either direct or through legitimate intermediate institutions or representatives. It is important to point out that representative democracy does not necessarily mean that the concerns of the most vulnerable in society would be taken into consideration in decision making. Participation needs to be informed and organized. This means freedom of association and expression on the one hand and an organized civil society on the other hand.

Rule of law in Good governance requires fair legal frameworks that are enforced impartially. It also requires full protection of human rights, particularly those of minorities. Impartial enforcement of laws requires an independent judiciary and an impartial and incorruptible police force.

Transparency means that decisions taken and their enforcement are done in a manner that follows rules and regulations. It also means that information is freely available and directly accessible to those who will be affected by such decisions and their enforcement. It also means that enough information is provided and that it is provided in easily understandable forms and media.

In the sphere of responsiveness Good governance requires that institutions and processes try to serve all stakeholders within a reasonable timeframe.

Good governance is consensus oriented. There are several actors and as many view points in a given society. Good governance requires mediation of the different interests in society to reach a broad consensus in society on what is in the best interest of the whole community and how this can be achieved. It also requires a broad and long-term perspective on what is needed for sustainable human development and how to achieve the goals 
of such development. This can only result from an understanding of the historical, cultural and social contexts of a given society or community.

Equity and inclusiveness are other principles of Good governance. A society's well being depends on ensuring that all its members feel that they have a stake in it and do not feel excluded from the mainstream of society. This requires all groups, but particularly the most vulnerable, have opportunities to improve or maintain their well being.

Effectiveness and efficiency are very important in Good governance. It means that processes and institutions produce results that meet the needs of society while making the best use of resources at their disposal. The concept of efficiency in the context of good governance also covers the sustainable use of natural resources and the protection of the environment.

Accountability is a key requirement of good governance. Not only governmental institutions but also the private sector and civil society organizations must be accountable to the public and to their institutional stakeholders. Who is accountable to whom varies depending on whether decisions or actions taken are internal or external to an organization or institution. In general an organization or an institution is accountable to those who will be affected by its decisions or actions. Accountability cannot be enforced without transparency and the rule of law.

From the above discussion it should be clear that good governance is an ideal which is difficult to achieve in its totality. Very few countries and societies have come close to achieving good governance in its totality. However, to ensure sustainable human development, actions must be taken to work towards this ideal with the aim of making it a reality ${ }^{5}$.

Council of Europe proposes to consider not eight, but 12 principles of Good democratic governance: participation, representation, fair conduct of elections; responsiveness; efficiency and effectiveness; openness and transparency; rule of law; ethical conduct; competence and capacity; innovation and openness to change; sustainability and long-term orientation; sound financial management; human rights, cultural diversity and social cohesion; accountability also ${ }^{6}$.

We recommend to introduce the TOTE cognitive model of Good Governance, which is based on mathematical models, authored by

\footnotetext{
5 Yap Kioe Sheng Economic and Social Commission for Asia and the Pacific. Retrieved from: https://www.unescap.org/sites/default/files/good-governance.pdf

${ }^{6}$ Principles of good democratic governance governance. Centre of expertise for local government reform (2018). Retrieved from: https://rm.coe.int/12-principles-of-governance-poster-a2/1680787986
} 
G.A. Miller, E. Galanter, and K.H. Pribram (Miller, Galanter, and Pribram, $1960)^{7}$ in natural resource management. This model is based on effect of a cognitive process which must include monitoring devices that control the acquisition of the stimulus-response relationship.

The TOTE model is the self-control mechanisms in management tasking, which are explained in terms of both operations and monitoring processes. In this model each recurring operation would be associated to a monitoring process, to test if the intended control was met or not. Its premise is that a common algorithm for solving non-deterministic problems in a complex natural-economic system, is to test where the system is currently, then perform some operation that makes a change, then retest again, and to repeat this until the answer is satisfactory, at which point the process is complete and ends (or exits). TOTEs are often nested within other TOTEs, since as a means to meet a goal, they are applicable to sub-goals too. The generic TOTE structure is: Test to obtain some representation of the problem state in natural-resource management; Operate - intervene in some way to solve the problem; Test again to see if the desired result has been achieved. If it has not, loop back to operate. If it has: Exit - when problem is solved according to previously obtained format of results by the instrument of project management.

Governance can be used in several contexts such as corporate governance, international governance, national governance and local governance. Since governance is the process of decision-making and the process by which decisions are implemented, an analysis of governance focuses on the formal and informal actors involved in decision-making and implementing the decisions made and the formal and informal structures that have been set in place to arrive at and implement the decision. Government is one of the actors in governance. Other actors involved in governance vary depending on the level of government that is under discussion. In rural areas, for example, other actors may include influential land lords, associations of peasant farmers, cooperatives, research institutes, religious leaders, finance institutions political parties, the military etc. The situation in urban areas is much more complex - at the national level, in addition to the above actors, media, lobbyists, international donors, multi-national corporations, etc. may play a role in decision-making or in influencing the decision-making process.

${ }^{7}$ George A. Miller, Eugene Galanter, and Karl H. Pribram (1960). Plans and the structure of behavior. New York: Henry Holt, 226 p. 
All actors other than overnment and the military are grouped together as part of the "civil society.» In some countries in addition to the civil society, organized crime syndicates also influence decision-making, particularly in urban areas and at the national level. Similarly formal government structures are one means by which decisions are arrived at and implemented. In some rural areas locally powerful families may make or influence decisionmaking. Such, informal decision-making is often the result of corrupt practices or leads to corrupt practices ${ }^{8}$.

There is considered that basic approaches to modernization of managerial system according to Good Governance management model includes:

- decentralization and introduction of cluster-corporative form of structural management in natural resources sphere;

- implementation of the complex economic estimation of natural resources in the system mechanism of management of natural resources;

- organizing of structure shifts with change of the property categories on municipal and corporative forms of property;

- introduction of the most latest instrument and forms of management the securitization of natural resources, corporative, cluster, project and other innovation programming and economic methods of management of natural resources etc.

As a fact, Good governance at all levels is fundamental to economic growth, political stability, and security. Central government and local communities must work together to tackle many aspects of weak governance, including corruption and money-laundering, and to promote full respect of the rule of law, increase transparency, and develop effective legislation in natural resources sphere as the foundation of a functioning state.

In the modern economy of the 21st century, which is to become first and foremost a sustainable economy, natural resources will act not only as an element of commodity production, but also as a component of the development of any socio-economic entity that requires appropriate institutionalization of natural-resource relations. This is emphasized, in particular, in the materials of the historic Rio + 20 Summit. The Rio 2012 Resolution "The Future We Want" is an important international document

\footnotetext{
${ }^{8}$ Yap Kioe Sheng Economic and Social Commission for Asia and the Pacific. Retrieved from: https://www.unescap.org/sites/default/files/good-governance.pdf

${ }^{9}$ United Nations (2012). The future we want. Outcome of the Conference on Sustainable Development. (A/CON F.216/L.1). Retrieved from: https://rio20.un.org/sites/rio20.un.org/files/a-conf.2161-1_russian.pdf.pdf
} 
that emphasizes that the institutionalization of the economic process in terms of natural-resource relations is an integral part of such an innovative economy and one of the main prerequisites for the continued sustainable development of society.

Therefore, it became necessary to transform the organizational structure of natural resources management in innovative directions at all levels of public administration in Ukraine, taking into account the processes of decentralization and, in this connection, changing the functions, mechanisms and powers for the sustainable development of territories. At the present stage of development of our country, the problem of the lack of a proper model of nature management at different levels leads to obstacles in the implementation of public administration. Therefore, the study of foreign experience will allow us to effectively apply the models of European countries in the management of natural resources. The key issues are related to defining the features of the European approach to the implementation of decentralized type of management of natural resources in the long term, and directions of their implementation in Ukraine.

\section{CONCLUSION}

It is necessary to use modern approaches of natural capital management, which are based on accounting of natural capital wealth and capitalization of natural resources now, to take into account actual, but hidden and not shown usefulness, value features and system ecological characteristic in each type of resource - land, water, wood and mineral resources, and in ecological system capital, created by all set of productive force of naturalanthropogenous ecological systems, which comprise all available types of resources. Specific recommendations of the Rio+20 contain information about the natural capital effect on the economic process. There are also some initial guidelines that show how natural resources, including water, land, forestry, minerals and other components of the environment should be adequately estimated. Conceptual innovation approaches of "Green", "Blue" and "Nano" economy and "Good governance" forms the basis of new management toolbox. It is determined that the modernization of managerial system of natural resources must provide creation of the high effective infrastructure of full-fledged attraction of natural resources in economic process through capitalization of them, including financial component, connected with corporative forms of natural resources management. 
Good governance is an approach to government that is committed to creating a system founded in justice and peace that protects individual's human rights and civil liberties. According to the United Nations, Good Governance is measured by the eight factors of participation, rule of law, transparency, responsiveness, consensus oriented, equity and inclusiveness, effectiveness and efficiency, and accountability. Participation requires that all groups, particularly those most vulnerable, have direct or representative access to the systems of government. Rule of Law is exemplified by impartial legal systems that protect the human rights and civil liberties of all citizens. Transparency means that citizens understand and have access to the means and manner in which decisions are made. Responsiveness simply involves that institutions respond to their stakeholders within a reasonable time frame. Consensus Oriented is demonstrated by an agenda that seeks to mediate between the many different needs, perspectives, and expectations of a diverse citizenry. Equity and Inclusiveness depends on ensuring that all the members of a community feel included and empowered to improve or maintain their well being. Effectiveness and Efficiency is developed through the sustainable use of resources to meet the needs of a society. Sustainability refers to both ensuring social investments carry through and natural resources are maintained for future generations. Accountability refers to institutions being ultimately accountable to the people and one another.

It is recommend to introduce the TOTE cognitive model of Good Governance, in natural resource management. This model is based on effect of a cognitive process which must include monitoring devices that control the acquisition of the stimulus-response relationship. The TOTE model is the self-control mechanisms in management tasking, which are explained in terms of both operations and monitoring processes. The generic TOTE structure is: Test to obtain some representation of the problem state in natural-resource management; Operate - intervene in some way to solve the problem; Test again to see if the desired result has been achieved. If it has not, loop back to operate. If it has: Exit - when problem is solved according to previously obtained format of results by the instrument of project management.

Basic approaches to modernization of managerial system according to Good Governance management model includes: decentralization and introduction of cluster-corporative form of structural management in natural resources sphere; implementation of the complex economic 
estimation of natural resources in the system mechanism of management of natural resources; organizing of structure shifts with change of the property categories on municipal and corporative forms of property; introduction of the most latest instrument and forms of management - the securitization of natural resources, corporative, cluster, project and other innovation programming and economic methods of management of natural resources etc. Central government and local communities must work together to tackle many aspects of weak governance, including corruption and moneylaundering, and to promote full respect of the rule of law, increase transparency, and develop effective legislation in natural resources sphere as the foundation of a functioning state.

\section{SUMMARY}

It is determined that nature is a system which requires systemic thinking. With regard to the documents of the Rio +20 summit, to the most urgent issues belongs creation of models for sustainable territorial development that should be based on the concept of efficient local resources usage, first of all natural. The conceptual approach includes, firstly, understanding of natural resource as a capital and, secondly, capitalization as a process of such resource transformation into surplus value and profit. As experts of the World Bank claim, for the most developed countries, the share of natural capital alongside with other tangible capital in the national wealth is about $20 \%$. The rate of the Ukraine's natural wealth, calculated according to current techniques manuals, in 2012 as of the latest year, which was relatively auspicious economically, comprised in value terms a bit more than USD 130 billion and exceeds the declared personal wealth of anyone among the richest people all over the world. In the nearest future we have not only to undertake a comprehensive valuation of natural capital, but also to provide all necessary backgrounds for launching its converting into financial shape. The answer to the question whether Ukraine is rich or poor, lies in adequate overall economic assessment of natural resources and their successful implementation into full-fledged capital by all means and tools of the modern economy of the XXI century. There is offered modernization of managerial system of natural resources in Ukraine through introduction of mechanism of the Good Governance and conception of corporative social and ecological responsibility and mechanism of the Public-Private Partnerships (PPP). 


\section{REFERENCES}

1. Kleiner, G. (2004). Nanoeconomics. Questions of Economy, 12, 70-93.

2. Pauli, G. (2010). The Blue Economy: 10 years -100 innovations 100 million jobs. Boulder, CO: Paradigm Publishers, 386 p.

3. Blueprint for a green economy: David Pearce, Anil Markandya and Edward B. Barbier. Earthscan, London, Great Britain (1989). 192 p.

4. A guidebook to the Green Economy Issue 1: Green Economy, Green Growth, and Low-Carbon Development - history, definitions and a guide to recent publications Division for Sustainable Development, UNDESA: Cameron Allen and Stuart Clouth, UN Division for Sustainable Development, (2012). 64 p.

5. Yap Kioe Sheng Economic and Social Commission for Asia and the Pacific. Retrieved from: https://www.unescap.org/sites/default/files/ good-governance.pdf

6. Principles of good democratic governance governance. Centre of expertise for local government reform (2018). Retrieved from: https://rm.coe.int/12-principles-of-governance-poster-a2/1680787986

7. George A. Miller, Eugene Galanter, and Karl H. Pribram (1960). Plans and the structure of behavior. New York: Henry Holt, $226 \mathrm{p}$.

8. United Nations (2012). The future we want. Outcome of the Conference on Sustainable Development. (A/CON F.216/L.1). Retrieved from: https://rio20.un.org/sites/rio20.un.org/files/a-conf.2161-1_russian.pdf.pdf

\section{Information about the author: Klynovyi D. V.} Candidate of Economics, Associate Professor, Senior Researcher, Public Institution "Institute of Environmental Economics and Sustainable Development of the National Academy of Sciences of Ukraine" 60, Boulevard Shevchenko, Kyiv, 01032, Ukraine 